\title{
Inverted pyramid Azores - an eternal hybrid structure
}

\section{Luís Pedro F R Sarmento Esteves}

Aalborg University, Fredrik Bajers Vej 7K, Aalborg East, 9220, Kingdom of Denmark BÖ01 Lda (2002-2004), Porto, Portugal (former)

luispedroesteves@hotmail.com

Article history
Received: March 19, 2021
Revised: May 22, 2021
Accepted: May 28, 2021
Acknowledgements
Structural analysis and finite element optimi-
zation of our hybrid inverted pyramid was
performed by Eng. Filipe Arteiro. The author
wishes to kindly acknowledge his effort, sha-
red enthusiasm, and engagement in the pro-
ject, and in particular his work on optimiza-
tion of our structural model to this project.
The minor engagement by Eng. Jorge Oliveira
is also kindly acknowledged, in particular
the discussion on construction feasibility, and
quantity surveying to initiate the tender.

\section{Contributions}

Luís Pedro F R Sarmento Esteves (PhD) structural design, material selection and project management; Filipe Arteiro (MSc) structural analysis and finite element optimization; Jorge Oliveira (BSc) - quantity surveyor and construction methods.

\begin{abstract}
Engineering structures are designed with observation of rules for structural performance under specific design loads, defined in the so-called structural codes. While dead loads are directly dependent from the selection of structural materials to a given structural function, live and accidental loads are often linked to the region where the structure must perform. In a complete opposition to engineering principles in Ancient Egypt, the inverted pyramid was designed to become a statement of how to bend gravitational laws, and what can be achieved by modern engineering, sill with intelligence to fulfill its function in a region where engineering structures are subjected to extreme live and accidental load regimes, e.g. high risk of earthquakes and high wind seasonal loads. A hybrid structural concept was specified, comprising lightweight structural wall elements anchored to a relatively heavyweight structural core. The suggested design concept fulfills the global equilibrium equation defined by architecture, and should become a structural example from a structural design perspective. As any other project involving non-comprehensive geometry, design and construction of the inverted pyramid is highly sensible to management options, which shall assure high precision manufacturing, and accurate control of its production.
\end{abstract}

Keywords: structural engineering, complex structures, hybrid structures, steelreinforced concrete structures, structural design, noble structures, inverted pyramids, history of engineering

\footnotetext{
For citation

Sarmento Esteves L.P.FR. Inverted pyramid Azores - an eternal hybrid structure. Structural Mechanics of Engineering Constructions and Buildings. 2021;17(3):261-269. http://dx.doi.org/10.22363/1815-5235-202117-3-261-269
}

\section{Л.П.ФР. Сарменто Эстевеш \\ Ольборгский университет, Королевство Дания, 9220, Ольборг, пр-кт Фредрика Байера, д. 7 К ВÖ01 Lda (2002-2004), Португальская Республика, Порту \\ luispedroesteves@hotmail.com}

Перевернутая пирамида на Азорских островах - вечная гибридная конструкция

\author{
История статьи \\ Поступила в редакцию: 19 марта 2021 г. \\ Доработана: 22 мая 2021 г. \\ Принята к публикации: 28 мая 2021 г.
}

\begin{abstract}
Аннотация. Инженерные сооружения проектируются с учетом правил эксплуатации конструкций при определенных расчетных нагрузках, регламентируемых строительными нормами. В то время как нагрузки от собственного веса напрямую зависят от выбора материалов для несущей конструкции,
\end{abstract}

Luís Pedro F R Sarmento Esteves, PhD and Scientist in Civil Engineering, MSc in Civil and Construction Engineering; Scopus Author ID: 24481021500, ORCID: https://orcid.org/0000-0002-2989-0284

Луис Педро ФР Сарменто Эстевеш, доктор философии, магистр в области гражданского строительства; Scopus Author ID: 24481021500, ORCID: https://orcid.org/0000-0002-2989-0284

(C) Sarmento Esteves L.P.FR, 2021

(C) () This work is licensed under a Creative Commons Attribution 4.0 International License 


\begin{abstract}
Благодарности
Конечноэлементный расчет и оптимизация конструкции в виде гибридной перевернутой пирамиды выполнены инженером Филипе Артейро. Автор выражает признательность за его усилия, энтузиазм и участие в проекте, в частности за работу по оптимизации авторской модели для данного проекта. Также заслуживает упоминания инженер Хорхе Оливейра, участвовавший в обсуждении целесообразности строительства и техникоэкономической оценке для составления коммерческого предложения.
\end{abstract}

\section{Вклад участников}

Луис Педро ФР Сарменто Эстевеш, $(\mathrm{PhD})$ проектирование конструкции, выбор материалов и управление проектами; $\Phi u$ липе Aртейро (магистр) - расчет конструкций и оптимизация методом конечных элементов; Хорхе Оливейра (бакалавр) вопросы, касающиеся геодезия и технологии строительства.

\section{Для цитирования}

Sarmento Esteves L.P.FR. Inverted pyramid Azores - an eternal hybrid structure // Строительная механика инженерных конструкций и сооружений. 2021. Т. 17. № 3. C. 261-269. http://dx.doi.org/10.22363/18155235-2021-17-3-261-269 временные и особые нагрузки диктуются назначением и областью применения этой конструкции. В противоположность инженерным принципам Древнего Египта перевернутая пирамида была спроектирована с целью показать, что с помощью современной инженерной науки можно преодолеть закон гравитации, причем эта «умная» конструкция выполняет свои функции в регионе, где инженерные сооружения подвергаются экстремальным и аварийным нагрузкам, например, в сейсмоопасных районах или регионах с преобладанием сильных ветров. Исследована гибридная концепция, которая предполагает легкие конструктивные стеновые элементы, закрепленные на относительно тяжелом структурном ядре. Предлагаемая концепция проектирования удовлетворяет уравнению глобального равновесия, определяемому самой архитектурой сооружения, и может служить примером сооружения, созданного в тренде перспективных направлений проектирования строительных конструкций. Как и любой другой проект конструкции с неполной геометрией, проектирование и строительство перевернутой пирамиды представляется весьма целесообразным при использовании схем управления производством, которые должны обеспечивать высокую точность изготовления и соответствующий контроль.

Ключевые слова: строительное проектирование, сложные конструкции, гибридные конструкции, железобетонные конструкции, перевернутые пирамиды, история инженерного дела

\section{Introduction: theoretical}

Egypt contains a few of the most remarkable early age "engineering" projects in the world, dated from the foremost prime centuries of human development. Engineering structures have evolved in almost all the aspects since that period, although archeology has often described those projects by simple or inexistent mathematical models containing more or less elaborated construction processes, centered in the manufacture of stone, to construct primordial large scale structures with no gravitational instability, e.g. large scale pyramids and temples (Giza, or other major temples) [1].

As far as human knowledge can reach, this primary approach to "engineering" based on such simple and rather intuitive "mathematics" has not greatly evolved through many centuries, just read R. Marcolongo (1937), on arches and vaults, in [2] - "an arch is nothing but a strength caused by two weaknesses", viz. meaning that and arch is elementary constituted by single weak structural parts, acquiring structural stability due to their structural assembly, or, “...these quarter-circles, each very weak in itself, wish to fall, and opposing each other's ruin, convert weakness into a single strength".

Inversely, to think giving structural integrity to an Inverted Pyramid involves primarily a degree of thorough considerations in the domain of structural engineering, as any decision will influence the ability and structural performance of such unstable solid in service, beyond the most advanced mathematical theories ever brought to us [3-6].

The suspension of a solid in space can be relatively easily solved by the use of cables attached to arch peers, such as the case of stay-cable bridges (see first stay-cable bridge) [7]. A second possibility is the use of post-tension in specific structural elements to resolve or minimize large local stresses and subsequent elastic deformations which would be generated by those large suspended structures, such as cantilevers, whereas its maximum span can be expanded from a couple of meters up to 7 meters, after remarkable developments in structural engineering [7-8].

Thus, in principle, any of the approaches are technically viable to be used in the structural design of an inverted pyramid, up to a certain scale and geometry, defined by the span allowance and geometrical freedom within their intrinsic safety boundaries. There are not many practical cases being proposed to fulfill such incomprehensive geometry and anti-gravity present in an inverted pyramid. The well-known classical example is of course brought by Oscar Niemeyer [8], in Brasilia, and later, Venezuela. In the first case, a massive reinforced 
concrete structure is suggested as structural solution, while the second case has not found any formal engineering description, or construction. A second, although minor example in terms of scale, is found performing in the Louvre, part of the renovation work commissioned directly by the French President, Mr. Francois Mitterrand, which was completed in 1989 [9]. A thin steel frame suspends an Inverted Pyramid in Glass, used as structural system. However, this "glass sculpture" is designed and engineered to perform without any major significant live or service load, being prohibited to any human interaction. The third and final example hereafter, and probably the most challenging project developed to Porto Cultural City, through the World Heritage Prize defined by UNESCO bi-annually, is the contemporaneous Music House in Portugal (2000), awarded to OMA Partners [10]. The use of post-tensioned concrete wall elements to fulfill large architectural and structural spans specified for the building, have shown to be appropriate to service the "imaginary" section of an inverted pyramid. Recall that Porto is located in a region characterized by medium levels of earthquake risk.

The structural engineering of the inverted pyramid designed to Azores, Portugal (2002), involves a third concept, consisting in the definition of a hybrid structure, described in the following sections.

\section{Structural design of the inverted pyramid}

The inverted pyramid is designed with formal structural parts comprising reinforced concrete, and structural steel frames, defining a hybrid structure. A mass foundation in reinforced concrete is specified on the theoretical vortex of the pyramid to assure its global equilibrium, and to offset combined effects produced by the dead load of the singularity, and those resultant from the natural gravitational movement by the inverted pyramid, coupled with any acting horizontal live load, viz. wind and earthquake (see structural section shown in Figure 1). Optimization through finite element analysis is performed on the full solid part, whereas structural steel is designed by direct application of method of forces combined with elasticity theory, to specify a columnbeam structural frame [11].

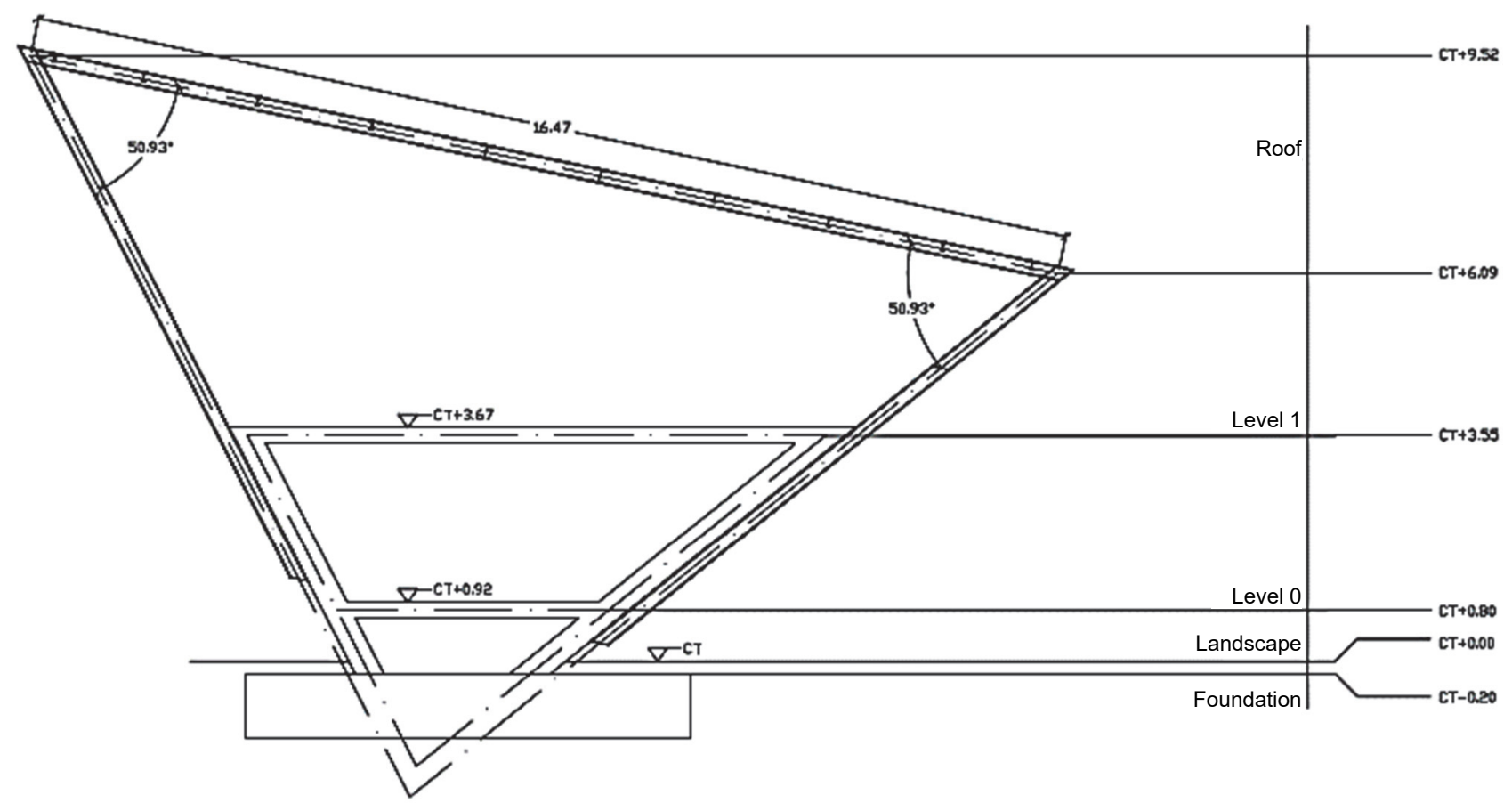

Figure 1. Structural cross section of the different levels of the pyramid (meters), taken through the horizontal plane

The structural design consisting in the definition of "lightweight" roof and wall system has as consequence a substantial reduction of the dead load acting on the structural core. This decision results in an effective dead load reduction of $75 \%$, and effective stress reduction of more than $300 \%$ on the anchor level of the pyramid, when compared with a standard wall structural system, such as structural concrete, or other special structural systems. In fact, the use of structural concrete as superstructure would in fact make this project economical not viable, considering the installed development capacity in Azores, and technically, without elaborated design 
options such as post tension in most of the structural parts of the structure. The center of gravity of this pyramid is also of special consideration, as it is slightly tilted, therefore, generating natural gravitational displacement towards its east facade. A massive foundation is installed to counteract this effect, beyond its typical standard function with regards to concrete structures. In addition, the inverted geometry generates automatically composed and deviated bending in any of the structural parts of the pyramid, adding additional complexity to design and structural analysis.

Facade 3

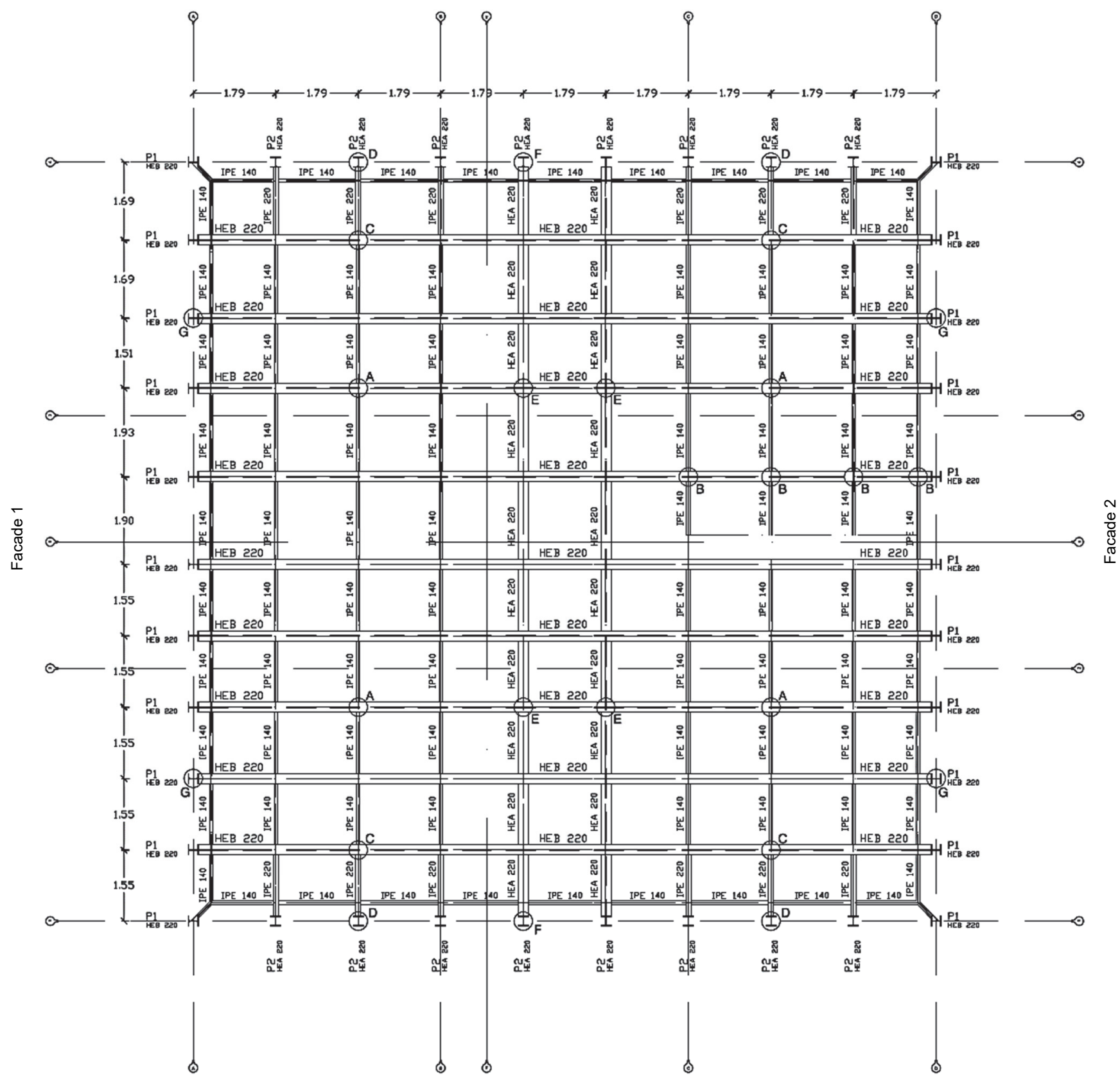

Facade 3

Figure 2. Structural plan for the roof (meters), with definition of structural facades (1-3). H profiles with $220 \mathrm{~mm}$ are specified for the highest span (longitudinal axis). Maximum deflection is found at $\mathrm{X} / 2$ and $\mathrm{Y} / 2$, and equals approximately $7 \mathrm{~mm}$ 


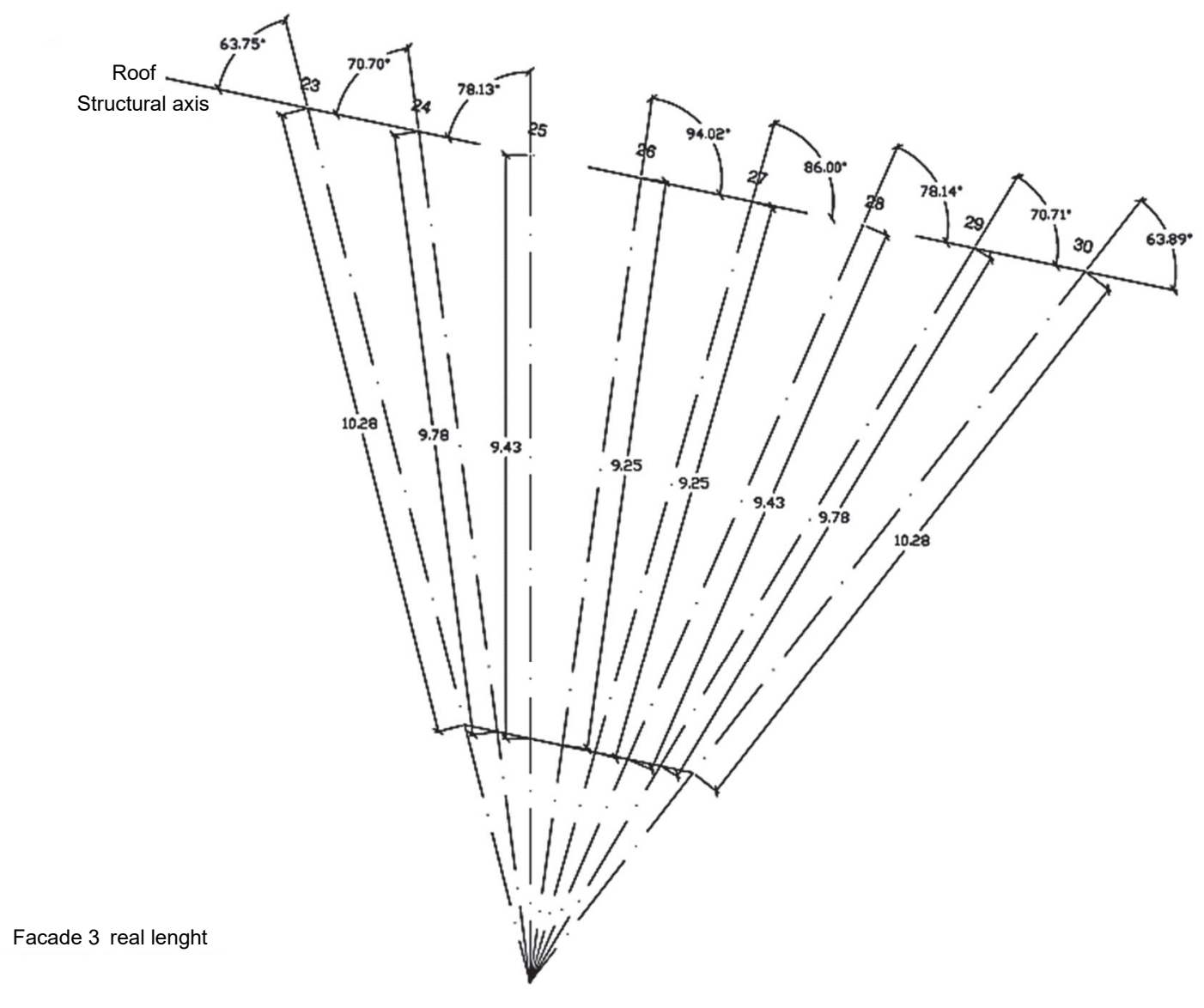

$a$

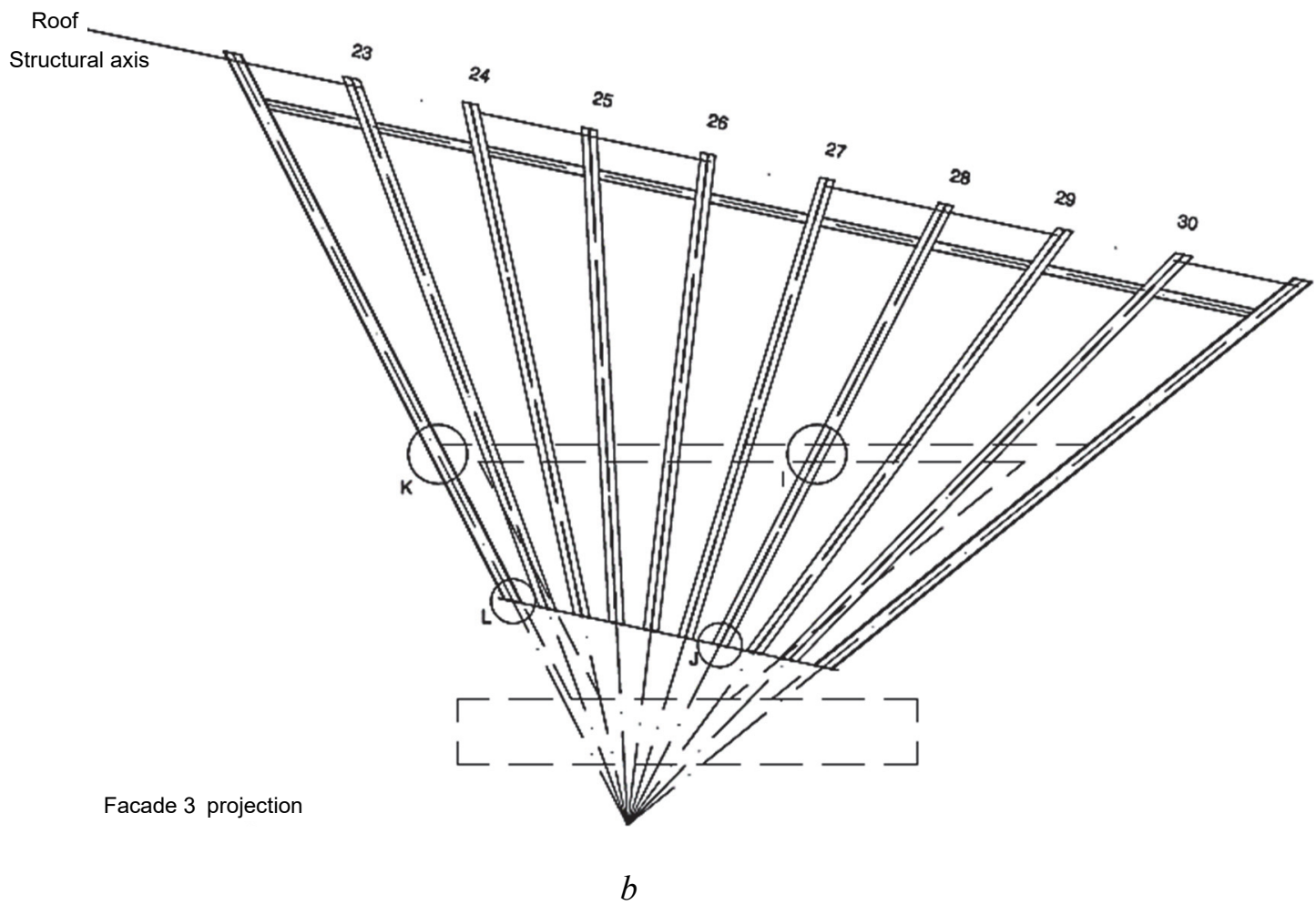

Figure 3. Steel frame specified to wall system in facade 3:

$a$ - real length of the structural elements; $b$ - projection in the $\mathrm{x}$-axis and definition of joint types 
Detail I (ESC:1:10)

Front view

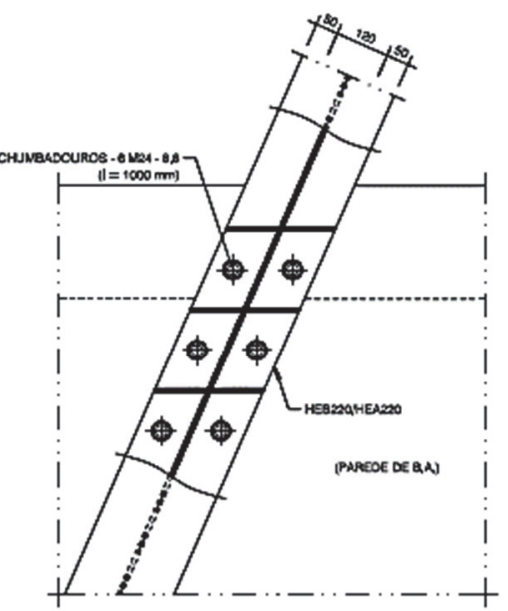

Lateral view

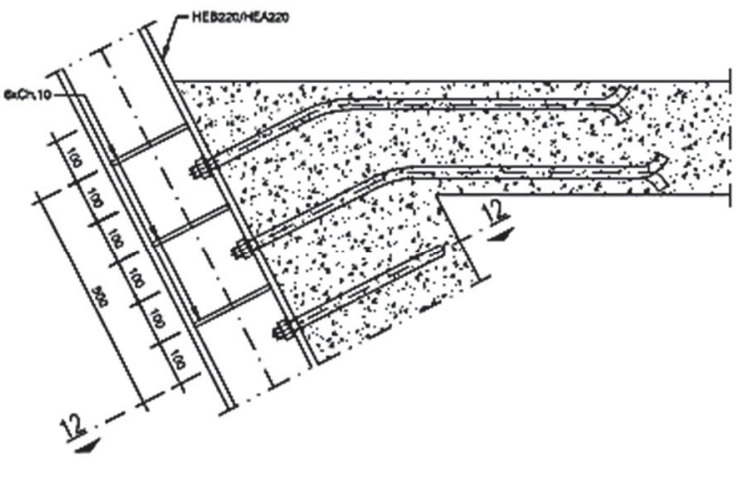

Section $12-12$

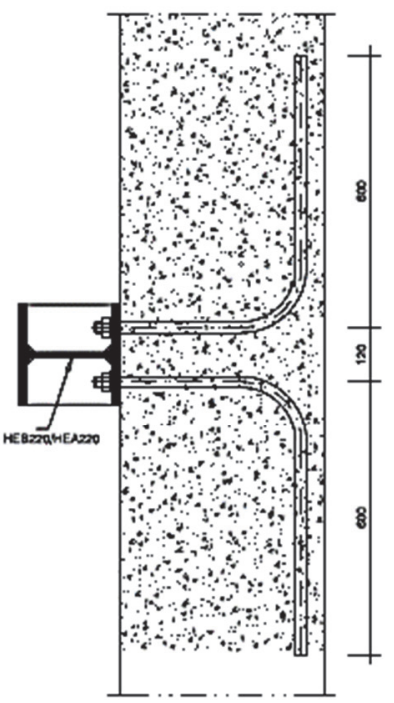

$a$

Detail J (ESC:1:10)

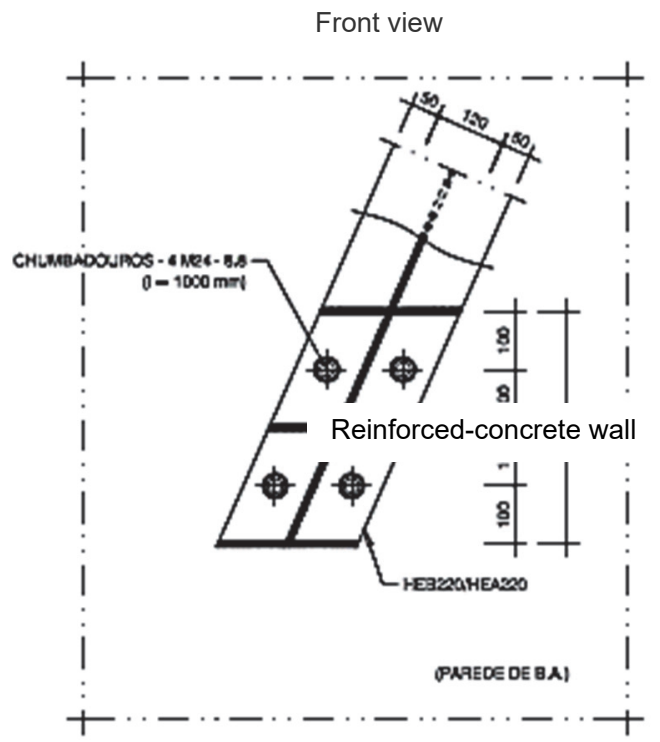

Lateral view

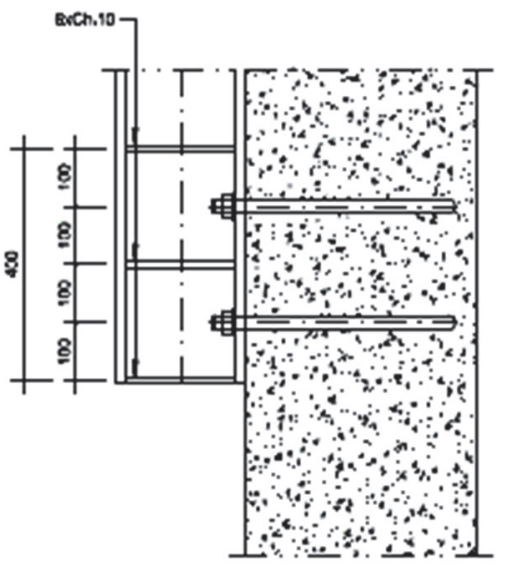

$b$

Figure 4. Detail of the anchor points for the connection of the steel shell and reinforced concrete structure: $a$-detail I, with 6 connectors and correspondent stabilizing plates; $b$ - detail J, with 4 connectors and correspondent stabilizing plates

A steel mesh of $\mathrm{H}$ and I profiles was chosen as superstructure (Figure 2). $\mathrm{H}$ profiles with height of $220 \mathrm{~mm}$, are set to perform in a span of $17 \mathrm{~m}$. Due to the tilted geometry of the pyramid, the longitudinal direction of the mesh was prioritized to resistance and the perpendicular direction, prioritized to stability. Expansion joints $(\mathrm{G})$ are installed in $\mathrm{H}$ beams to allow horizontal displacements due to e.g. thermal deformations, and integrity of the pair beam-column. H columns are defined coherently with the same section and inertia in the shell superstructure (facades 1-3). A detailed geometry of the steel mesh elaborated for the wall system is shown in Figure 3 (facade 3 ), where real length of each column is defined. 
The shell structure of the inverted pyramid is fully constituted by the defined steel frame, whereas insulation may be placed on the available space left by steel, or beneath it. In the outer skin, stone may be suspended, while the interior skin may comprise finishing in wood or blended wood-mortar panels. This leads to an average dead load of less than $0.5 \mathrm{kN} / \mathrm{m}^{2}$, less than the live load considered characteristic in the roof. As nearly all stress generated by any horizontal live or accidental load event will tend to concentrate on the steel frame, stresses are quickly transferred by steel columns and stabilizing beams comprising the wall units towards their anchor points, which are positioned in the concrete structural core (see Figure 3). A detail of such anchor points is shown in Figure 4, designed to pull out structural contribution from the concrete core into the global stability of the structural shell, although additional constructive precautions are raised. The anchor points $\mathrm{I}-\mathrm{J}$ will develop resistance to e.g. rotation in about 6 to 9 points, absorbing or releasing stresses in the axial plane of the reinforced concrete floor, coupled with the anchor point positioned in the wall unit. The limit state of this type of connection is greater than the pull out strength of reinforcement bars in concrete, viz. $0.24 \sqrt{f_{c k}}$ to $0.32 \sqrt{f_{c k}}\left(\mathrm{~N} / \mathrm{mm}^{2}\right)$, as it also mobilizes opposing resistant compressive strength exerted by structural concrete (see Figure 4, detail I, section 12-12), as far as yield strength in the screws installed on the head of the connector is not reached.

\section{Structural analysis}

The optimization of floor and wall units comprising the structural core was performed by means of finite element analysis (FEM). A linear element was selected for this purpose, from where stress and strain is derived, and reinforcement may be defined, according to stress-strain analysis performed in each structural element. The approach followed the concept of ultimate limits state for 24 load combinations, in order to isolate the most unfavorable load case. This corresponded to the dead load of the structure, coupled with live load imposed by service. The simulation of ultimate and service limit states is obtained from the following general expression, whereas the correspondent design coefficients are utilized [11].

$$
S_{d}=\sum_{i=1}^{m} \gamma_{g i} S_{G i k}+\gamma_{q}\left[S_{Q s k}+\sum_{j=2}^{n} \psi_{0 j} S_{Q j k}\right],
$$

where, $S_{G i k}$ - stress resultant from characteristic values of dead load; $S_{Q s k}$ - stress resultant from characteristic values of live load; $S_{Q j k}$ - stress resultant from characteristic values of remaining live loads (except earthquakes). Minoring and majoring coefficients are set according to design regulations defined elsewhere [11].

Structural integrity is achieved by assuring that the design loads are lower than the resistant load, viz. $S_{d} \leq R_{d}$ is fulfilled.

The stress-strain analysis performed show maximum tensions appearing in level 1, due to bending, larger than any major tension (tensile) operating in any part of concrete wall elements, with exception to stress concentration located at the anchor points and singularities, where dead and live loads transferred from the superstructure (steel part) induce stress-strain of considerable magnitude. In particular, the interface of the floor and wall units in facade 2, which corresponds to the steepest angle formed by the inverted pyramid, concurs the highest internal tension in any section of the structure, originating composed compression and tensile stress. A direct comparison with stress-strain in the same region at the opposite facade (1) is elucidatory about how inverted geometry has a tremendous effects in design of reinforced concrete structures, with variations of more than $75 \%$ (absolute value of stress), for a differential increment of $25^{\circ}$ in the angle with the hypothetical vertical plane Z. The maximum stress operating in reinforced concrete of the inverted pyramid is in fact situated at the interface between the floor and the concrete wall unit, that will be subjected to permanent shear force produced by the dead load of the steel superstructure, coupled with the axial tension generated by structural concrete to opposed horizontal displacements. This permanent load has however a positive effect on bending, and it will reduce deformation in concrete elements in the opposite direction (vertical section plane - YY), as in the case of pre-tensed or post-tensed reinforced concrete. The slab at level 1 will be subjected to permanent axial tension with average value of $100 \mathrm{KN} / \mathrm{m}$ and up to $400 \mathrm{KN} / \mathrm{m}$, in singularities of the structure (such as the encounters of wall units, and slabs throughout the section).

To exemplify the application of ultimate limit state in structural concrete, Figure 5 is elaborated, showing the quantity of reinforcement required to fulfill structural integrity in the concrete slab (level 1), predefined with height of $200 \mathrm{~mm}$. Up to $5 \mathrm{~cm}^{2} / \mathrm{m}$ are required to be distributed in the perpendicular direction with regard to the horizontal plane to hinder tensile stresses due to bending, in the tensioned region of the section plane. The load case refers to the ultimate limit state combination 12 (dead load and corresponding live load characterristic in public spaces), whereas the bending moment of $25 \mathrm{KN} \cdot \mathrm{m}$ will not lead to any major deflection, being 
admitted the contribution of both internal and external bearing walls, designed to hinder rotation of the bearing by specifying reinforcement at the compressed region of the plane, that will take up the double of the value of the bending moment at half span. The evaluation of the maximum deflection in the slab, so that the minimum crack width criterion of 0.2 in ultimate limit state is fulfilled, is within the limit of $\mathrm{L} / 400$, with a maximum distance between reinforcement limited to $150 \mathrm{~mm}$ in the tensioned region of the section plane. This is particularly relevant in external walls, due to marine environment that Azores is geographically linked to.

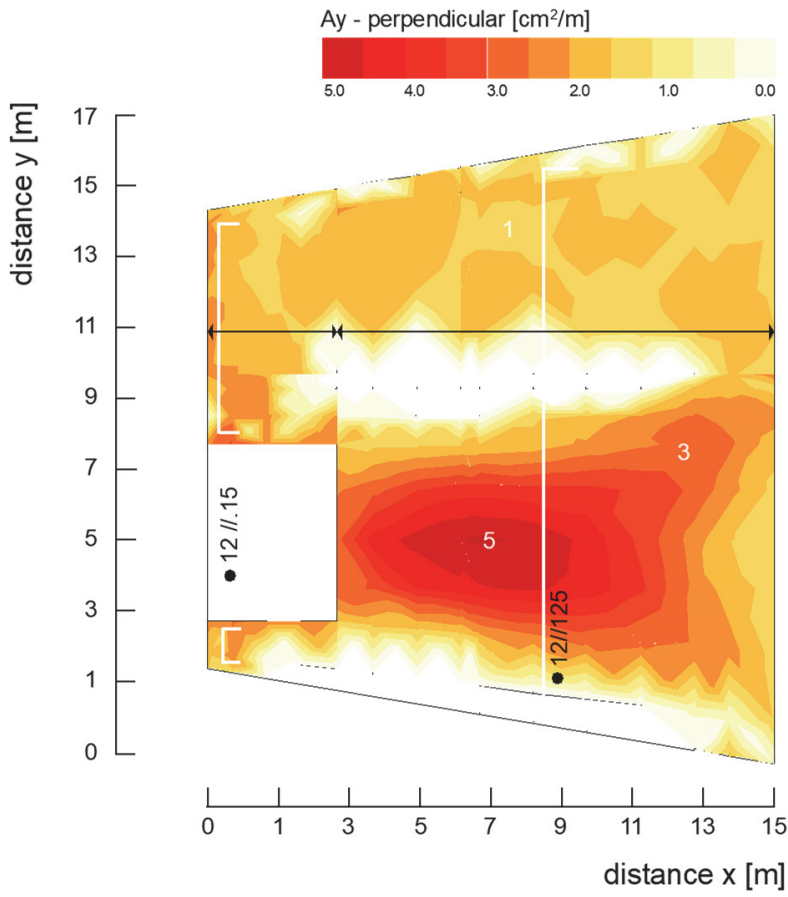

Figure 5. Result of FEM and subsequent stress-strain analysis performed in the main concrete slab (level 1) of the inverted pyramid (negative position of the section plane), from where reinforcement is defined. The load case refers to the ultimate limit state combination 12 (dead load and corresponding live load characteristic in public spaces)

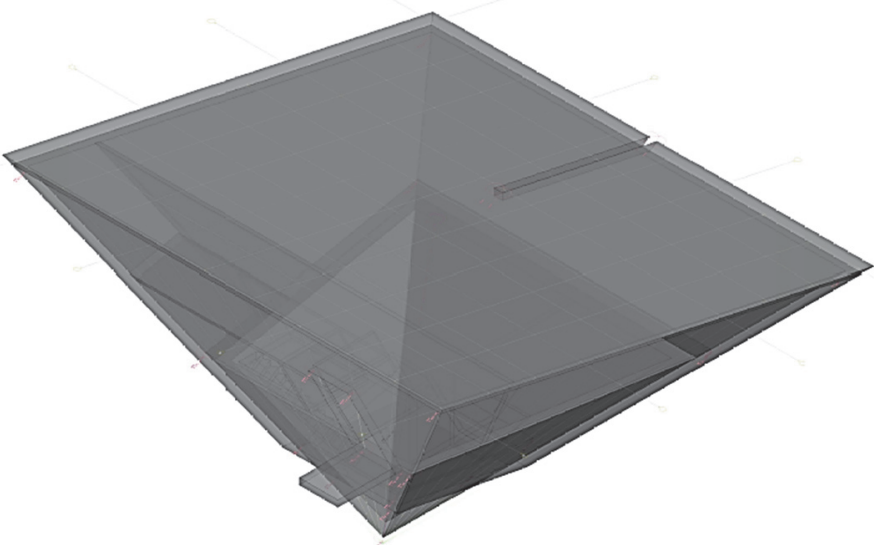

Figure 6. 3D perspective of the inverted pyramid (without scale) credits to James Grainger for the development of the 3D model in $\mathrm{CAD}[1]$

The inverted pyramid (Figure 6), in the most unfavorable load case, will be able to stand up to $4000 \mathrm{KN}$ of force into the mass foundation, and hinder rotations up to $4000 \mathrm{KN} \cdot \mathrm{m}$.

\section{Economics of the inverted pyramid}

The tender to launch the inverted pyramid in Azores is based on pricing with reference to 2004 . The predicted cost of construction is less than 0.25 million euros, whereas structural costs represents $70 \%$ of the tender. The cost can be breakdown in about $70 \%$ to steel structures, and the remaining to reinforced concrete structures. The environmental footprint of the project may be elaborated from the mass of each structural system, combined with known characteristic environmental footprint from production. Manufacturing high precision hybrid structures requires accurate production techniques, whereas tolerances shall be restricted to those utilized in the production of steel structures. The complexity of the defined geometry, lead to specification of unique parts in structural elements, in particular the elements composing the steel structure, where each profile has unique dimensions. Such complexity is only compatible with high precision construction methods.

\section{Final remarks}

Structural design of this inverted pyramid is an example of how gravitational forces of a theoretical unstable solid can reach equilibrium by using smart structural design and modern engineering analysis and calculus. The proposed structural solution targeted the reduction and optimization of dead loads acting on the structure, while holding its safety parameters. 
The use of a standard steel frame will fulfill a free span of 17 meters, with a predicted deflection of $70 \mathrm{~mm}$. Structural wall elements coupling steel elements and insulation have reduced the stress on structural elements such as reinforced concrete structural parts, and foundation. The steel-concrete connection solution adds structural integrity to the system, by pulling structural contribution from the concrete slabs and wall units as resistant elements towards horizontal and vertical loads, within ultimate and service limit state for 24 load combinations.

This approach permitted a feasible and reasonable design of the inverted pyramid, without the use of relatively heavyweight superstructures, and high concentration of steel rods or post tension cables in concrete structural elements, which would require to use special construction techniques, and would represent a duplication of the economy needed to fulfill this project.

Structural design of an inverted pyramid is not a common project in engineering work. Beyond the complexity in design and analysis from a structural point of view, it raises many challenges to production methods, only compatible to rather high accuracy, due to limited allowances that are already characteristic in the manufacturing of steel structures.

Although the scale of the project is not large, when compared to a couple of thousand-meter bridge, we consider this project part of the world heritage of engineering, in the elegancy of its time.

\section{References}

1. Edwards I.E.S. The pyramids of Egypt. Revised edition (first published 1947). Penguin Books; 1986.

2. Benvenuto E. An introduction to the history of structural mechanics. Part II. Vaulted structures and elastic systems. Springer-Verlag; 1991.

3. Hook R. De potencia restitutive. Londres; 1678.

4. Maxwell J.C. On the calculation of the equilibrium and stiffness of frames. The Scientific Papers of James Clerk Maxwell. 1890;2:175-177.

5. Castigliano A. Théorie de l'equilibre des systèmes élastiques. Turin; 1879.

6. Mohr O. Beitrag zur theorie des fachwerks. Zeitschrift des Architekten und Ingenour-Vereins zu Hannover (vol. 20). Hannover: Schmorl \& von Seefeld; 1874.

7. Brücken F.L. Äesthetic und gestaltung. Stuttgart: Deutsche Verlag-Anstalt; 1984.

8. Underwood D.K. Oscar Niemeyer and the architecture of Brazil. New York: Rizzoli; 1994.

9. Grand Louvre: phase I. Pei Cobb Freed \& Partners.

10. OMA Partners - Music House in Porto. 2000.

11. Eurocodes, CEN. 1997-2020. 